\title{
Pengaruh Creative Tourist Experience, Travel Motivation dan Perceived Risk Terhadap Revisit Intention Pada Wisata Edukasi Secara Virtual
}

\author{
Novyta Putri Mayasari*; Yessy Artanti \\ Jurusan Manajamen, Fakultas Ekonomika dan Bisnis, Universitas Negeri Surabaya \\ Jl. Ketintang, Ketintang, Kec. Gayungan, Kota Surabaya 60231 \\ *novyta.17080574039@mhs.unesa.ac.id
}

\begin{abstract}
The development of the progress of tourism potential is currently increasing with the emergence of tourist changes in attracting tourist. Tourism managers are required to be able to provide tourist comfort to maintain the popularity of tourism even during a pandemic. Some tourism managers during the pandemic offer virtual educational tours. This study aims to analyze the effect of creative tourist experience, travel motivation and perceived risk on revisit intention. This research uses non probability sampling and judgmental sampling method to target respondents. The respondent is someone who was visited the Surabaya Zoo virtually during the Covid-19 pandemic, with a vulnerable age of 13-50 years as many as 200 respondents. The data analysis technique used multiple regression. The results of this study indicate that creative tourist experience and travel motivation have significant effect on revisit intention. Meanwhile, perceived risk has no significant effect on revisit intention.
\end{abstract}

Keywords : Creative Tourist Experience, Travel Motivation, Perceived Risk, Revisit Intention, Virtual.

\begin{abstract}
Abstrak - Perkembangan kemajuan potensi pariwisata saat ini terus meningkat dengan munculnya perubahan-perubahan wisata dalam menarik perhatian wisatawan. Pengelola wisata dituntut dapat memberikan kenyamanan wisatawan untuk mempertahankan popularitas wisata bahkan ketika pada masa pandemi. Beberapa pengelola wisata dimasa pandemi menawarkan wisata edukasi secara virtual. Penelitian ini bertujuan untuk menganalisis pengaruh creative tourist experience, travel motivation dan perceived risk terhadap revisit intention pada wisata edukasi secara virtual. Penelitian ini menggunakan non probability sampling dengan judgment sampling. Responden adalah seseorang yang telah mengunjungi Kebun Binatang Surabaya secara virtual di masa pandemi Covid-19, dengan rentan usia 13-50 tahun sebanyak 200 responden. Teknik analisis data menggunakan regresi berganda. Hasil penelitian ini menunjukkan bahwa creative tourist experience dan travel motivation berpengaruh signifikan terhadap revisit intention. Sedangkan perceived risk tidak berpengaruh signifikan terhadap revisit intention.
\end{abstract}

Kata Kunci : Creative Tourist Experience, Travel Motivation, Perceived Risk, Revisit Intention, Virtual.

\section{PENDAHULUAN}

Pariwisata merupakan salah satu sektor penunjang perekonomian Indonesia yang selalu mengalami peningkatan setiap tahunnya. Industri pariwisata Indonesia menempati peringkat ke-9 di dunia dengan sektor yang tumbuh paling cepat versi The World Travel and Tour Council (WTTC)[1]. Keberadaan sektor pariwisata dapat memberikan multiplier effect pada sektor ekonomi, karena secara tidak langsung pariwisata akan mendorong tumbuhnya sektor-sektor lain yang berkaitan erat dengan pariwisata. Pada tahun 2020 peningkatan pendapatan devisa pada sektor pariwisata tidak mampu bertahan dengan stabil, hal ini disebabkan oleh kehadiran virus Covid-19 (Coronavirus Desease). Badan Kesehatan Dunia (WHO) menyatakan bahwa virus Covid-19 dinyatakan sebagai pandemi global yang merubah tatanan kehidupan dalam aspek global mapun nasional serta menjadi cobaan terberat bagi sektor perekonomian Indonesia[2]. Menurut Wishnutama Kusubandio, Menteri Pariwisata dan Ekonomi Kreatif, menilai akibat pandemi dan penutupan semua tempat rekreasi dan hiburan, mobilitas masyarakat menjadi terbatas sehingga berdampak besar pada perekonomian industri pariwisata[2]. Seiring berjalanannya waktu virus Covid-19 dapat dikendalikan, pada awal juni 2020 Pemerintah menerapkan kebijakan new normal (cara hidup baru di tengah pandemi berdasar pada protocol kesehatan) yang membawa dampak baik bagi sektor pariwisata di Indonesia.

Terdapat beberapa faktor yang dapat menstimuli wisatawan untuk berkunjung yaitu faktor psikologis (minat kepribadian, hobi, profesi, sikap, persepsi dan pemahaman terhadap lingkungan sekitar)[3]. Faktor yang kedua yaitu pengalaman yang akan mepengaruhi bagaimana mereka melakukan keputusan mengenai kegiatan pariwisatanya. Semakin pesatnya perkembangan wisata, destinasi pariwisata dihadapkan dengan persaingan yang cukup ketat. Destinasi wisata perlu meningkatkan loyalitas dari wisatawan agar tetap mengalahkan destinasi lainnya. Loyalitas merupakan kesetiaan seseorang dalam waktu yang lama, dimana 
mereka melakukan pembelian secara teratur dan perilaku pembelian tidak dilakukan secara acak dalam memilih keputusan[4]. Terdapat dua alternatif dalam konsep loyalitas wisatawan, yaitu sikap pembelian ulang dan analisis kecenderungan wisatawan dalam memilih destinasi wisata[5]. Revisit intention dan rekomendasi kepada orang lain merupakan indikator yang umum digunakan loyalitas[6]. Dalam jangka panjang, kunjungan wisata yang dilakukan lebih dari sekali terbukti lebih murah daripada melakukan kunjungan pertama kali dan pertumbuhan berkelanjutan dari sektor pariwisata[7].

Salah satu faktor yang menyebabkan wisatawan untuk berkunjung ulang (revisit intention) adalah pengalaman dari aktivitas berkunjung sebelumnya[8]. Pengalaman perjalanan di masa lalu dapat mempengaruhi sikap wisatawan baik secara positif maupun negatif dalam mengunjungi kembali suatu destinasi[9]. Pengalaman wisatawan tidak hanya menekankan partisipasi, interaktivitas dan kreasi wisatawan, tetapi juga menekankan jenis pengalaman lainnya misalnya pendidikan dan pengalaman dari pelarian[10]. Pengalaman wisatawan mencakup interaksi antar budaya, aktivitas wisata, kualitas layanan dan kepuasan hiburan[8]. Karakteristik dari pengalaman wisatawan yaitu melarikan, ketenangan pikiran, keterlibatan unik, interaktifitas dan pembelajaran[11].

Niat wisatawan dalam mengunjungi kembali tempat wisata tidak hanya dipengaruhi oleh pengalaman kreatif dari wisatawan, tetapi mereka digerakkan oleh motif yang mendorongnya untuk melakukan kegiatan berwisata[3]. Motivasi merupakan kekuatan psikologis internal yang muncul dari kebutuhan yang tidak terpuaskan, yang kemudian mendorong individu untuk terlibat dalam perilaku atau pemenuhan kebutuhan tertentu[12]. Motivasi wisatwan dianggap sebagai kekuatan pendorong yang memotivasi seseorang untuk berlibur atau mengunjungi suatu destinasi. Motivasi perjalanan merupakan faktor terpenting dalam perilaku wisatawan, dan kemungkinan besar motivasi perjalanan mempengaruhi mereka untuk berkunjung ulang[6]. Motivasi perjalanan dalam perilaku wisata dapat dibagi menjadi dua faktor yaitu faktor pendorong (push) dan faktor penarik (pull) yang mengarahkan individu untuk melakukan perjalanan[12]. Motivasi perjalanan dianggap sebagai kekuatan pendorong awal balik perilaku, dan kemungkinan besar motivasi akan mempengaruhi sikap wisatawan terhadap niat berkunjung dan mengunjungi kembali[9].
Selain pengalaman dan motivasi wisatawan, revisit intention juga dipengaruhi oleh perceived risk[13]. Perceived risk mengacu pada persepsi konsumen tentang kemungkinan suatu tindakan[12]. Jika risiko yang dirasakan dianggap melebihi batas, dapat memaparkan mereka pada bahaya yang dapat mempengaruhi keputusan perjalanan. Persepsi risiko merupakan determinan penting dari publik kesediaan untuk terlibat dalam perilaku perlindungan kesehatan. Risiko juga dapat mempengaruhi perilaku seseorang dalam konteks bahaya baru yang dapat diamati dan tidak dapat diprediksi seperti Covid-19[14]. terdapat enam faktor dalam persepsi risiko yang disebabkan oleh manusia yaitu keuangan, kualitas layanan, sosiopsikologis, bencana alam dan kecelakaan mobil serta masalah keamanan cuaca[13]. Wisatawan mungkin melihat masalah risiko secara berbeda karena variasi geografi, budaya, psikologi dan pengalaman perjalanan yang dapat mempengaruhi niat perilaku mereka dengan cara yang berbeda[15]. Terdapat tiga tipologi risiko yang paling relevan dengan kemungkinan wisatawan melakukan perjalanan wisata pasca pandemi Covid-19 yaitu kesehatan, psikologis dan resiko sosial[16]. Risiko kesehatan dalam pariwisata dikaitkan dengan potensi bahaya bagi kesehatan dan kesejahteraan wisatawan ketika terlibat dalam kegiatan perjalanan dan pariwisata. Terlepas dari resiko kesehatan yang dirasakan terkait dengan pandemi Covid-19, sifat unik pandemi juga dapat memperburuk risiko psikologis dan sosial.

Tingginya kasus Covid-19 menyebabkan wisatawan enggan untuk mengunjungi tempat wisata meskipun Pemerintah telah menetapkan era new normal dengan meyiapkan protokol kesehatan kepada pengunjung wisata. Namun, tetap saja kegiatan wisata yang dilakukan secara langsung mempunyai risiko yang sangat tinggi. Adanya kemajuan teknologi saat ini mampu membuat manusia untuk lebih mudah bertukar informasi mengenai tempat wisata yang sulit dikunjungi di masa pandemi Covid-19. Dengan memanfaatkan teknologi yang ada kegiatan pariwisata masih dapat dilakukan melalui virtual tour[17]. Meskipun Jawa Timur menduduki urutan kedua dengan kasus covid tertinggi di Indonesia, namun pariwisata di Jawa Timur setelah ditetapkannya era new normal perlahan mulai bangkit dan menunjukkan tren positif[18]. Salah satu kota di Jawa Timur yang sering dikunjungi oleh wisatawan adalah Kota Surabaya. Petugas Dinas Kebudayaan dan Pariwisata (DISBUDPAR) Kota Surabaya berupaya untuk beradaptasi dengan situasi saat ini dengan melakukan pembaruan tempat wisata agar bisa dikunjungi secara

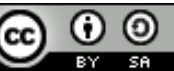


daring melalui virtual tour. Virtual tour dikhususkan untuk wisata edukasi yang bertujuan untuk mengedukasi anak serta menghilangkan kejenuhan ketika sekolah daring. Wisata yang selalu menjadi primadona tujuan wisata pilihan keluarga untuk menikmati liburannya yaitu Kebun Binatang Surabaya atau KBS[19]. Meskipun KBS telah menerapkan virtual tour untuk wisatawan, namun jumlah pengunjung dinilai belum maksimal bahkan data kunjungan di akhir tahun 2020 penurunan pengunjung mencapai 1000 setiap harinya[20]. Penelitian ini bertujuan untuk mengetahui pengaruh antara variabel creative tourist experience, travel motivation dan perceived risk terhadap revisit intention pada wisata edukasi secara virtual di Kebun Binatang Surabaya.

\section{KAJIAN PUSTAKA}

\section{Revisit Intention}

Revisit intention merupakan determinasi wisatawan untuk mengunjungi kembali suatu destinasi wisata[21]. Revisit intention adalah segmen yang menarik bagi destinasi wisata, terutama karena pertimbangan biaya dan efektivitas peristiwa destinasi seni merupakan suatu hal penting bagi industri pariwisata[5]. Revisit intention didasarkan oleh kesediaan wisatawan untuk mengunjungi destinasi yang sama atau obyek wisata lain di destinasi yang sama[22]. Berdasarkan definisi tersebut, dapat disimpulkan bahwa revisit intention merupakan niat seseorang untuk mengunjungi kembali suatu destinasi wisata atau obyek destinasi yang sama sebelumnya.

\section{Creative Tourist Experience}

Creative tourist experience merupakan pengalaman yang dibentuk dalam pikiran manusia yang bersifat unik dan emosional dengan nilai personal yang tinggi[23]. Pengalaman wisatawan mencakup interaksi antar budaya, aktivitas manusia, kualitas layanan dan kepuasan hiburan[11]. Berdasarkan definisi tersebut, disimpulkan bahwa creative tourist experience adalah pengalaman unik yang dirasakan wisatawan ketika melakukan perjalanan pada suatu destinasi.

\section{Travel Motivation}

Motivation merupakan kekuatan psikologis internal yang muncul dari kebutuhan yang tidak terpuaskan, yang kemudian mendorong individu untuk terlibat dalam perilaku atau kebutuhan tertentu[12].
Travel motivation merupakan kondisi yang membangkitkan dorongan dalam diri wisatawan untuk mencapai tujuannya[24]. Kemudian, motivasi perjalanan adalah rangkaian kebutuhan yang membuat seseorang mau untuk berpartisipasi dalam suatu kegiatan dan berusaha untuk mendapatkan kepuasan yang diinginkan[25]. Berdasarkan dari definisi tersebut, dapat disimpulkan bahwa travel motivation merupakan dorongan dari dalam keinginan psikologis seseorang yang menyebabkan adanya tindakan untuk melakukan perjalanan pada suatu tempat.

\section{Perceived Risk}

Perceived risk merupakan determinan penting dari kesediaan untuk terlibat dalam perlindungan Kesehatan[14]. Risiko dapat mempengaruhi perilaku seseorang dalam konteks bahaya baru yang dapat diamati dan tidak dapat diprediksi seperti virus Covid19. Perceived risk sebagai persepsi konsumen tentang probabilitas bahwa suatu tindakan dapat memaparkan mereka pada bahaya yang dirasakan dianggap malampaui batas[12]. Berdasarkan definisi tersebut, dapat disimpulkan bahwa perceived risk merupakan persepsi seseorang tentang ketidakpastian dan konsekuensi buruk atau risiko yang mungkin terjadi ketika membeli suatu produk atau layanan.

\section{Pengaruh Creative tourist experience dengan Revisit intention}

Hasil penelitian dari beberapa ahli menyatakan bahwa creative tourist experience berpengaruh positif dan signifikan terhadap revisit intention[8]. Pada penelitian tersebut dibuktikan dengan ditemukannya responden memiliki daya ingat lebih tinggi terhadap kegiatan yang dilakukan ketika mengunjungi destinasi wisata sehingga mendorong mereka untuk mengunjungi kembali destinasi wisata tersebut. Sejalan dengan hal tersebut hasil penelitian lain menunjukkan bahwa creative tourist experience berpengaruh signifikan terhadap revisit intention yang berarti pengalaman wisatawan merupakan faktor yang mempengaruhi niat mereka untuk mengunjungi kembali destinasi wisata[26]. Pengalaman wisatawan yang didapatkan ketika berkunjung di suatu destinasi wisata dengan baik dan menarik dapat meningkatkan keinginan pengunjung untuk berkunjung kembali pada destinasi wisata tersebut. Berdasarkan bukti empiris di atas, peneliti mengajukan hipotesis sebagai berikut: 
H1 : Creative tourist experience berpengaruh signifikan terhadap revisit intention.

\section{Pengaruh Travel motivation dengan Revisit intention}

Hasil penelitian sebelumnya menyatakan bahwa teori push dan pull merupakan motif sosio-psikologis yang mendorong seseorang untuk melakukan kegiatan berwisata sehingga pada penelitian tersebut membuktikan bahwa travel motivation berpengaruh signifikan terhadap revisit intention[21]. Hasil penelitian tersebut juga didukung oleh penelitian lain yang menunjukkan bahwa travel motivation memiliki pengaruh positif terhadap revisit intention[9]. Dalam penelitian tersebut travel motivation dianggap sebagai komponen penting yang membuat seseorang mau untuk berpartisipasi dalam suatu kegiatan dan berusaha untuk mendapatkan kepuasan yang diinginkan. Namun, berbeda dengan hasil penelitian para ahli lain yang menunjukkan bahwa travel motivation berpengaruh tidak signifikan terhadap revisit intention[6]. Dalam penelitian tersebut travel motivation tidak cukup kuat dalam memengaruhi seseorang untuk berkunjung ulang pada destinasi wisata jika tidak didorong dengan faktor internal seperti faktor psikologis. Dari kajian teori tersebut terjadi inkonsistensi sehingga terdapat peluang untuk meneliti tentang travel motivation terhadap revisit intention. Berdasarkan bukti empiris di atas, peneliti mengajukan hipotesis sebagai berikut:

$\mathrm{H} 2$ : Travel motivation berpengaruh signifikan terhadap revisit intention

\section{Pengaruh perceived risk dengan Revisit intention}

Hasil penelitian dari para ahli menunjukkan bahwa perceived risk berpengaruh signifikan terhadap revisit intention[27]. Hal ini sejalan dengan penelitian oleh beberapa ahli yang menyatakan bahwa perceived risk berpengaruh signifikan terhadap revisit intention[28]. Sedangkan hasil penelitian lain menyatakan bahwa perceived risk berpengaruh tidak signifikan terhadap revisit intention[13],[15]. Adanya pengaruh tidak signifikan disebabkan karena seseorang masih mempertimbangkan beberapa risiko yang mungkin mereka dapatkan ketika mengunjungi destinasi wisata seperti risiko kesehatan, keamanan dan keuangan. Dari kajian teori tersebut terdapat inkonsistensi sehingga terdapat peluang untuk meneliti tentang perceived risk terhadap revisit intention.
Berdasarkan bukti empiris di atas, peneliti mengajukan hipotesis sebagai berikut:

H3 : Perceived risk berpengaruh signifikan terhadap revisit intention.

Berdasarkan hipotesis yang yang telah ditentukan, model penelitian dapat dilihat pada gambar 1 .

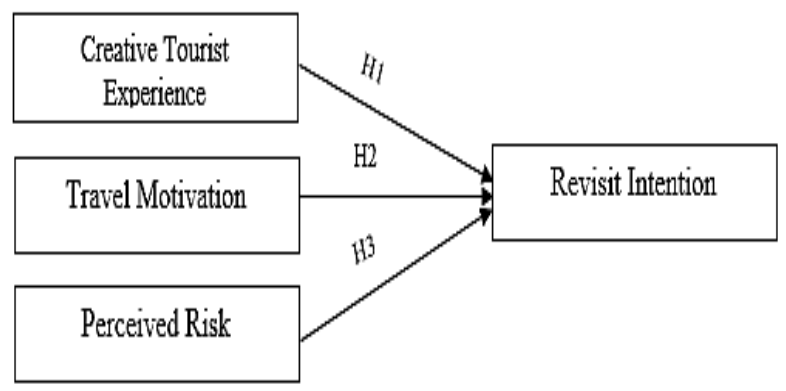

Gambar 1. Kerangka berpikir

\section{METODE PENELITIAN}

Jenis penelitian yang digunakan dalam penelitian ini adalah penelitian kuantitatif. Data sekunder yang digunakan dalam penelitian ini yang diperoleh dari studi pustaka dan internet research. Responden penelitian ini yaitu seseorang yang telah mengunjungi Kebun Binatang Surabaya secara virtual tour pada masa pandemi Covid-19 dengan rentang usia 13-50 tahun. Teknik sampling menggunakan non probability dengan judgmental sampling. Responden yang dibutuhkan sebesar 30 responden untuk uji validitas dan reliabilitas serta 200 responden untuk pengujian hipotesis. Pengukuran jawaban responden menggunakan skala likert dengan rentang 1 (sangat tidak setuju) sampai 5 (sangat setuju). Pengumpulan data dilakukan dengan menyebarkan kuesioner online di sosial media facebook, instagram, whatsapp story dan whatsapp group. Teknik analisis data menggunakan regresi linier berganda.

\section{HASIL DAN PEMBAHASAN}

\section{Hasil Uji Validitas dan Reliabilitas}

Pengujian validitas dan reliabilitas pada penelitian ini dilakukan pada 30 responden di luar dari responden penelitian ini. Berdasarkan hasil uji validitas, itemitem pengukuran pada penelitian ini dinyatakan valid dengan melihat nilai collerated item-total yang menghasilkan nilai $\mathrm{r}$ hitung $>\mathrm{r}$ tabel $(0,361)$. Sedangkan hasil pengujian reliabilitas pada penelitian ini dinyatakan reliabel karena menghasilkan nilai 
cronbach's alpha based on standardized items $>0,70$. Hasil uji validitas dan reliabilitas dapat dilihat pada tabel 1.

Tabel 1. Hasil Uji Validitas dan Reliabilitas

\begin{tabular}{|c|c|c|c|c|}
\hline No & $\begin{array}{c}\text { Variable } \\
\text { (2) }\end{array}$ & $\begin{array}{l}\text { Item } \\
(3)\end{array}$ & $\begin{array}{c}\text { Correlated } \\
\text { Item Total } \\
\text { (4) }\end{array}$ & $\begin{array}{c}\text { Croncbach } \\
\text { Alpha } \\
(5)\end{array}$ \\
\hline 1 & $\begin{array}{l}\text { Creative } \\
\text { Tourist } \\
\text { Experience }\end{array}$ & $\begin{array}{l}\text { Merasa rileks } \\
\text { selama berkunjung } \\
\text { secara virtual }\end{array}$ & 0,551 & 0,776 \\
\hline 2 & & $\begin{array}{l}\text { Merasa nyaman } \\
\text { berkunjung secara } \\
\text { virtual }\end{array}$ & 0,719 & \\
\hline 3 & & $\begin{array}{l}\text { Mendapatkan } \\
\text { pengalaman baru } \\
\text { Ketika berkunjung } \\
\text { secara virtual }\end{array}$ & 0,713 & \\
\hline 4 & & $\begin{array}{l}\text { Mendapatkan } \\
\text { pengalaman } \\
\text { berbeda ketika } \\
\text { berkunjung } \\
\text { virtual }\end{array}$ & 0,599 & \\
\hline 5 & & $\begin{array}{l}\text { Belajar banyak hal } \\
\text { ketika berkunjung } \\
\text { secara virtual } \\
\text { Membangkitkan }\end{array}$ & 0,807 & \\
\hline 6 & & $\begin{array}{l}\text { rasa ingin tahu } \\
\text { ketika berkunjung } \\
\text { secara virtual }\end{array}$ & 0,786 & \\
\hline 7 & & $\begin{array}{l}\text { Menambah } \\
\text { pengetahuan ketika } \\
\text { berkunjung secara } \\
\text { virtual }\end{array}$ & 0,799 & \\
\hline 8 & $\begin{array}{l}\text { Travel } \\
\text { Motivation }\end{array}$ & $\begin{array}{l}\text { Berkunjung secara } \\
\text { virtual untuk } \\
\text { bersenang-senang }\end{array}$ & 0,607 & \\
\hline 9 & & $\begin{array}{l}\text { Berkunjung secara } \\
\text { virtual untuk } \\
\text { mencari } \\
\text { petualangan baru }\end{array}$ & 0,725 & \\
\hline 10 & & $\begin{array}{l}\text { Berkunjung secara } \\
\text { virtual untuk } \\
\text { mengurangi stress }\end{array}$ & 0,593 & \\
\hline 11 & & $\begin{array}{l}\text { Berkunjung secara } \\
\text { virtual untuk } \\
\text { melakukan sesuatu } \\
\text { yang } \\
\text { menyenangkan }\end{array}$ & 0,847 & \\
\hline 12 & & $\begin{array}{l}\text { Berkunjung secara } \\
\text { virtual untuk rileks }\end{array}$ & 0,491 & \\
\hline 13 & & $\begin{array}{ll}\text { Berkunjung } & \text { secara } \\
\text { virtual } & \text { untuk } \\
\text { merasakan } & \\
\text { kegembiraan } & \end{array}$ & 0,614 & \\
\hline 14 & $\begin{array}{l}\text { Perceived } \\
\text { Risk }\end{array}$ & $\begin{array}{l}\text { Khawatir biaya } \\
\text { internet akan } \\
\text { meningkat ketika } \\
\text { melakukan virtual }\end{array}$ & 0,63 & 0,775 \\
\hline 15 & & $\begin{array}{l}\text { Merasa tidak aman } \\
\text { untuk memberikan } \\
\text { informasi pribadi } \\
\text { ketika berkunjung } \\
\text { secara virtual }\end{array}$ & 0,671 & \\
\hline
\end{tabular}

\begin{tabular}{|c|c|c|c|c|}
\hline No & $\begin{array}{c}\text { Variable } \\
\text { (2) }\end{array}$ & $\begin{array}{l}\text { Item } \\
(3)\end{array}$ & $\begin{array}{c}\text { Correlated } \\
\text { Item Total } \\
(4)\end{array}$ & $\begin{array}{c}\text { Croncbach } \\
\text { Alpha } \\
(5)\end{array}$ \\
\hline 16 & & $\begin{array}{lr}\text { Khawatir } & \text { orang } \\
\text { lain } & \text { dapat } \\
\text { mengakses } & \text { akun } \\
\text { saya } & \text { ketika } \\
\text { berkunjung } & \text { secara } \\
\text { virtual } & \end{array}$ & 0,8 & \\
\hline 17 & & $\begin{array}{l}\text { Khawatir } \\
\text { berkunjung secara } \\
\text { virtual akan } \\
\text { membuang waktu }\end{array}$ & 0,757 & \\
\hline 18 & & $\begin{array}{lr}\text { Waktu yang } \\
\text { diberikan } \\
\text { berkunjung } & \text { ketika } \\
\text { virtual tidak efisien }\end{array}$ & 0,666 & \\
\hline 19 & & $\begin{array}{l}\text { Berkunjung secara } \\
\text { virtual tidak sesuai } \\
\text { dengan saya }\end{array}$ & 0,83 & \\
\hline 20 & & $\begin{array}{l}\text { Layanan virtual } \\
\text { tidak menjelaskan } \\
\text { destinasi wisata } \\
\text { secara lengkap }\end{array}$ & 0,838 & \\
\hline 21 & & $\begin{array}{l}\text { Situs web virtual } \\
\text { sulit diakses }\end{array}$ & 0,673 & \\
\hline 22 & & $\begin{array}{l}\text { Berkunjung secara } \\
\text { virtual untuk } \\
\text { menghindari } \\
\text { bepergian ke kota } \\
\text { besar }\end{array}$ & 0,75 & \\
\hline 23 & $\begin{array}{l}\text { Revisit } \\
\text { intention }\end{array}$ & $\begin{array}{l}\text { Akan berkunjung } \\
\text { secara virtual } \\
\text { dalam waktu dekat }\end{array}$ & 0,851 & 0,803 \\
\hline 24 & & $\begin{array}{ll}\text { Mempunyai minat } \\
\text { yang kuat untuk } \\
\text { berkunjung secara } \\
\text { virtual }\end{array}$ & 0,776 & \\
\hline 25 & & $\begin{array}{l}\text { Akan berkunjung } \\
\text { untuk menikmati } \\
\text { fasilitas virtual } \\
\text { Akan }\end{array}$ & 0,75 & \\
\hline 26 & & $\begin{array}{l}\text { Akan } \\
\text { merekomendasikan } \\
\text { layanan virtual } \\
\text { kepada orang lain }\end{array}$ & 0,739 & \\
\hline 27 & & $\begin{array}{l}\text { Akan berkunjung } \\
\text { kembali melalui } \\
\text { virtual pada wisata } \\
\text { lainnya }\end{array}$ & 0,839 & \\
\hline
\end{tabular}

Sumber: Data diolah peneliti (2021)

\section{Karakteristik Responden}

Responden dari penelitian ini adalah seorang pelajar dan guru dengan rentan usia 13-50 tahun yang pernah berkunjung di Kebun Binatang Surabaya secara virtual tour di masa pandemi Covid-19. Hasil pengolahan data kuesioner menunjukkan bahwa karakteristik mayoritas responden adalah perempuan (73\%) dengan rentang usia antara 13-20 tahun dan 2131 tahun (49\%) dengan pendidikan terakhir adalah perguruan tinggi / universitas dan pekerjaan sebagai pelajar/mahasiswa $(84,5 \%)$. Mayoritas responden memiliki penghasilan < Rp $1.000 .000(77 \%)$. 


\section{Uji Asumsi Klasik}

Pada uji asumsi klasik yang digunakan yaitu uji normalitas, multikolinearitas, dan heteroskedastisitas. Berdasarkan hasil dari uji normalitas yang dilakukan menunjukkan data berdistribusi normal karena nilai signifikansi lebih besar dari 0,05 yakni sebesar 0,051, kemudian hasil uji multikolinearitas pada penelitian ini menunjukkan bahwa tolerance value dari creative tourist experience dan travel motivation yaitu 0,537 > 0,1 dan perceived risk yaitu 0,999>0,1. Begitu juga nilai VIF dari creative tourist experience dan travel motivation yaitu $1,863<10$ dan perceived risk yaitu $1,001<10$. Maka, dapat disimpulkan bahwa tidak terjadi multikolinearitas pada penelitian ini. Penelitian ini menunjukkan bahwa tidak ada gejala heteroskedastisitas sehingga penelitian mempunyai persamaan variance residual dalam satu periode pengamatan dengan periode pengamatan lain. Berdasarkan tiga uji asumsi klasik yang telah dilakukan hasil menunjukkan penelitian ini telah memenuhi uji normalitas, mutikolinearitas dan heteroskedastisitas. Sehingga data penelitian ini layak dilanjutkan ke analisis data untuk pengujian hipotesis. Kemudian pada uji kelayakan model menunjukkan bahwa nilai adjusted R Square sebesar 0,283 $=28,3 \%$, dimana hasil tersebut menunjukkan kontribusi antara variabel creative tourist experience, travel motivation dan perceived risk terhadap revisit intention di Kebun Binatang Surabaya sebesar 28,3\%.

\section{Uji Hipotesis}

Pengujian hipotesis pada penelitian ini menggunakan alat uji statistik regresi linier berganda untuk mengetahui pengaruh variabel bebas terhadap variabel terikat dengan cara melihat hasil nilai signifikansi. Apabila nilai signifikansi $<0,05$ maka variabel bebas dapat memengaruhi secara signifikan terhadap variabel terikat, dan sebaliknya jika nilai signifikansi > 0,05 maka variabel bebas dikatakan tidak memengaruhi variabel terikat. Hasil uji hipotesis dapat dilihat pada tabel 2 .

Tabel 2. Uji Hipotesis

\begin{tabular}{llc}
\hline & & Sig \\
\hline Creative Tourist Experience & $\rightarrow$ Revisit Intention & 0,000 \\
Travel Motivation & $\rightarrow$ Revisit Intention & 0,002 \\
Perceived Risk & $\rightarrow$ Revisit Intention & 0,167 \\
\hline
\end{tabular}

Sumber: Data diolah peneliti (2021)
Pada pengaruh antara creative tourist experience terhadap revisit intention nilai signifikansi sebesar $0,000 \leq 0,05$ maka creative tourist experience berpengaruh signifikan terhadap revisit intention. Sedangkan pengaruh antara travel motivation terhadap revisit intention dengan nilai signifikansi sebesar 0,002 $\leq 0,05$ yang dapat dinyatakan bahwa travel motivation berpengaruh signifikan terhadap revisit intention. Selanjutnya pengaruh antara perceived risk terhadap revisit intention menghasilkan nilai signifikansi sebesar $0,167 \geq 0,05$ maka perceived risk tidak berpengaruh signifikan terhadap revisit intention.

Kemudian uji regresi linier berganda yaitu menggunakan model analisis regresi linier berganda dengan persamaan $\mathrm{Y}=\mathrm{a}+\mathrm{b} 1 \mathrm{X} 1+\mathrm{b} 2 \mathrm{X} 2+\mathrm{b} 3 \mathrm{X} 3+$ $\ldots+$ bn $\mathrm{Xn}+$ e. Hasil uji regresi linier berganda dapat dilihat pada tabel 3 .

Tabel 3. Hasil Uji Regresi Linier Berganda

\begin{tabular}{lcc}
\hline & B & Sig \\
\hline Constant & 3,444 & 0,073 \\
\hline $\begin{array}{l}\text { Creative tourist } \\
\text { experience }\end{array}$ & 0,295 & 0,000 \\
\hline Travel Motivation & 0,262 & 0,002 \\
\hline Perceived Risk & 0,036 & 0,167 \\
\hline \multicolumn{2}{c}{ Sumber: Data diolah oleh peneliti $(2021)$}
\end{tabular}

Berdasarkan hasil uji regresi linier berganda diperoleh persamaan regresi linier berganda adalah Y $=3,444+0,295 \mathrm{X} 1-0,262 \mathrm{X} 2+0,036 \mathrm{X} 3$. Berdasarkan persamaan tersebut maka nilai konstanta $(\alpha)$ sebesar 3,444 menunjukkan bahwa creative tourist experience, travel motivation dan perceived risk sama dengan 0 maka besarnya revisit intention sebesar 3,444. Kemudian nilai positif pada konstanta menunjukkan bahwa meskipun tidak ada creative tourist experience, travel motivation dan perceived risk maka revisit intention tetap terjadi dengan nilai sebesar 3,444 . Nilai koefisien pada masing-masing variabel menunjukkan nilai positif terhadap variabel dependen. Yang artinya bahwa semakin bagus creative tourist experience, travel motivation dan perceived risk maka semakin meningkat revisit intention.

\section{Pembahasan}

Berdasarkan uji yang telah dilakukan, peneliti mendapatkan hasil bahwa creative tourist experience berpengaruh signifikan terhadap revisit intention. Artinya, apabila creative tourist experience meningkat atau menurun maka terdapat pengaruhnya terhadap 
revisit intention seorang wisatawan. Hasil tersebut menunjukkan bahwa hipotesis pertama yaitu "creative tourist experience berpengaruh signifikan terhadap revisit intention" pada wisatawan Kebun Binatang Surabaya secara virtual mendukung. Hasil dari penelitian ini mendukung pernyataan dari beberapa ahli bahwa creative tourist experience berpengaruh signifikan terhadap revisit intention[8], [26]. Adanya pengaruh signifikan antara creative tourist experience terhadap revisit intention dikarenakan disaat wisatawan hendak menentukan rencana tujuan destinasi, mereka mengandalkan pengalaman mengesankan sebelumnya yang dirasakan. Mereka menganggap bahwa wisata Kebun Binatang Surabaya secara virtual memberikan segala pengalaman yang berkesan yang ingin membuat wisatawan berkunjung kembali di masa yang akan datang. Kemudian dari hasil karakteristik responden, penelitian ini didominasi oleh perempuan dengan rentan usia 13-20 tahun yang memiliki status pelajar atau mahasiswa. Hal tersebut dikarenakan Kebun Binatang Surabaya merupakan salah satu wisata edukasi dengan layanan virtual tour yang menjadi primadona tujuan wisata bagi pelajar/mahasiswa untuk menikmati liburannya di masa pandemi. Perempuan dengan status pelajar/mahasiswa lebih memanfaatkan waktu luangnya dengan berlibur untuk menghilangkan kejenuhan ketika belajar daring. Wisatawan biasanya akan memilih destinasi wisata yang memberikan kenyamanan dan pengalaman relatif berbeda dari destinasi wisata lain, dimana Kebun Binatang Surabaya merupakan wisata yang cocok untuk dikunjungi oleh wanita yang masih tergolong muda karena mendapatkan pengalaman yang mengesankan ketika mengunjungi Kebun Binatang Surabaya secara virtual yang nantinya wisatawan akan ingin kembali mengunjungi lagi.

Berdasarkan hasil analisis yang didapatkan peneliti mengetahui bahwa travel motivation berpengaruh signifikan terhadap revisit intention. Apabila travel motivation meningkat atau menurun maka terdapat pengaruh terhadap revisit intention wisatawan. Hasil tersebut mendukung hipotesis kedua yaitu "travel motivation berpengaruh signifikan terhadap revisit intention pada wisatawan Kebun Binatang Surabaya. Penelitian ini memperkuat hasil penelitian dari beberapa ahli yang menyatakan travel motivation berpengaruh signifikan terhadap revisit intention[21], [9]. Adanya pengaruh signifikan antara travel motivation terhadap revisit intention dikarenakan ketika akan mengunjungi destinasi wisata, wisatawan digerakkan oleh motif yang mendorongnya untuk melakukan wisata. Mereka termotivasi mengunjungi Kebun Binatang Surabaya secara virtual untuk menghilangkan kejenuhan selama pandemi Covid-19 yang mengharuskan mereka untuk tetap dirumah. Jika dikaitkan dengan karakteristik responden, penelitian ini didominasi oleh perempuan dengan rentan usia 13-21 tahun yang memiliki status sebagai pelajar/mahasiswa. Hal tersebut dikarenakan wanita lebih memperhatikan keadaan dirinya untuk menghilangkan stress akibat belajar daring dengan melakukan kegiatan mengunjungi Kebun Binatang Surabaya secara virtual yang membuatnya senang. Maka, hal ini menunjukkan bahwa seseorang akan termotivasi akan mengunjungi kembali Kebun Binatang Surabaya secara virtual untuk melakukan sesuatu yang menyenangkan.

Penelitian ini menyatakan perceived risk tidak berpengaruh signifikan terhadap revisit intention. Hasil tersebut menolak hipotesis ketiga yaitu "perceived risk berpengaruh signifikan terhadap revisit intention" pada wisatawan Kebun Binatang Surabaya secara virtual. Penelitian ini memperkuat hasil penelitian dari beberapa ahli yang menyatakan bahwa perceived risk berpengaruh tidak signifikan terhadap revisit intention[13], [15]. Namun hasil penelitian ini tidak mendukung penelitian lain yang mengungkapkan bahwa perceived risk berpengaruh signifikan terhadap revisit intention[27], [28]. Terjadinya pandemi Covid-19 ternyata tidak menyurutkan niat seseorang untuk berkunjung pada suatu destinasi wisata. Adanya kemajuan teknologi saat ini, membuat mereka tetap bisa melakukan kegiatan berwisata meskipun secara virtual tanpa harus berkunjung secara langsung di tempat wisata. Untuk kunjungan secara online, pengunjung tidak terlalu memperdulikan resiko-resiko sebagaimana halnya dengan kunjungan secara offline. Selain hal tersebut, seseorang tidak memikirkan resiko yang mungkin terjadi ketika berkunjung di Kebun Binatang Surabaya secara virtual, karena mereka telah melakukan kunjungan serupa di masa pandemi dan akan melakukan kunjungan kembali. Jika dikaitkan dengan karakteristik responden, penelitian ini didominasi oleh responden rentan usia 13-21 tahun yang memiliki status sebagai pelajar/mahasiswa. Hal tersebut semakin mendukung bahwa responden dengan usia tersebut mempunyai antusias lebih tinggi untuk mengikuti berbagai kegiatan yang dilakukan di sekolahnya. Sehingga ketika kunjungan di Kebun Binatang Surabaya secara virtual diprogramkan dan wajib diikuti oleh pihak sekolah, mereka tidak begitu memikirkan resiko yang mungkin terjadi saat

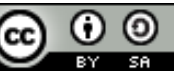


melakukan virtual tour. Maka, hal ini menunjukkan bahwa persepsi risiko atau perceived risk di Kebun Binatang Surabaya secara virtual tidak menyurutkan niat wisatawan untuk mengunjungi kembali Kebun Binatang Surabaya secara virtual.

\section{KESIMPULAN DAN SARAN}

\section{Kesimpulan}

Berdasarkan hasil dan pembahasan sebelumnya, kesimpulan pada penelitian ini adalah Creative tourist experience dan travel motivation berpengaruh signifikan terhadap revisit intention pada wisata edukasi virtual di Kebun Binatang Surabaya. Sedangkan perceived risk tidak berpengaruh signifikan terhadap revisit intention pada wisata edukasi virtual di Kebun Binatang Surabaya.

\section{Saran}

Berdasarkan pembahasan dan kesimpulan, berikut adalah saran untuk penelitian yang akan datang sekaligus implikasi manajerial dari penelitian ini. Keterbatasan pada penelitian ini tidak membedakan wisata edukasi virtual atas inisiatif pribadi atau atas inisiatif lembaga/sekolah. Disarankan penelitian selanjutnya membedakan dua konteks ini karena kemungkinan pengaruh persepsi risiko (perceived risk) dari dua konteks ini terhadap niat berkunjung ulang (revisit intention) adalah berbeda. Munculnya pandemi Covid-19 membuat industri pariwisata mengalami banyak penurunan yang salah satunya adalah menurunnya jumlah wisatawan. Peran para pelaku bisnis khususnya bidang pariwisata dan pemerintah sangat diperlukan dalam mengembalikan tatanan ekonomi nasional. Hasil dari penelitian ini diharapkan dapat membantu dalam kegiatan pemasaran pada Kebun Binatang Surabaya di masa pandemi dengan cara mendesain strategi pemasaran secara online dengan lebih menarik dan inovatif seperti halnya strategi pada pemasaran offline. Pemasar diharapkan dapat memperbarui vitur layanan virtual tour agar.

\section{REFERENSI}

[1] kompas.com, "Negara dengan Pertumbuhan Pariwisata Tercepat Sedunia, Indonesia Peringkat 9," www.kompas.com, 2018. https://travel.kompas.com/read/2018/10/04/18 1500527/negara-dengan-pertumbuhanpariwisata-tercepat-sedunia-indonesiaperingkat-9- (accessed Nov. 05, 2020).

[2] kompas.com, "WHO Resmi Sebut Virus Corona Covid-19 sebagai Pandemi Global," kompas.com,

2020. https://www.kompas.com/sains/read/2020/03/ 12/083129823/who-resmi-sebut-virus-coronacovid-19-sebagai-pandemi-global?page=all (accessed Nov. 14, 2020).

[3] N. Hidayah, Pemasaran Destinasi Pariwisata. Bandung: Alfabeta, 2015.

[4] V. Gaffar, CRM dan MPR Hotel (Customer Relantionship Management and Marketing Public Relations). Bandung: Alfabeta, 2007.

[5] A. Hasan, Tourism Marketing. Yogyakarta: CAPS (Center For Academic Publishing Service), 2015.

[6] M. Li, L. A. Cai, X. Y. Lehto, and J. Z. Huang, "A missing link in understanding revisit intention-the role of motivation and image," $J$. Travel Tour. Mark., vol. 27, no. 4, pp. 335-348, 2010, doi: 10.1080/10548408.2010.481559.

[7] S. Um, K. Chon, and Y. H. Ro, "Antecedents of revisit intention," Ann. Tour. Res., vol. 33, no. 4, pp. 1141-1158, 2006, doi: 10.1016/j.annals.2006.06.003.

[8] W. L. Hung, Y. J. Lee, and P. H. Huang, "Creative experiences, memorability and revisit intention in creative tourism," Curr. Issues Tour., vol. 19, no. 8, pp. 763-770, 2016, doi: 10.1080/13683500.2013.877422.

[9] S. Huang and C. H. C. Hsu, "Effects of travel motivation, past experience, perceived constraint, and attitude on revisit intention," $J$. Travel Res., vol. 48, no. 1, pp. 29-44, 2009, doi: $10.1177 / 0047287508328793$.

[10] S. K. Tan, D. B. Luh, and S. F. Kung, "A taxonomy of creative tourists in creative tourism," Tour. Manag., vol. 42, pp. 248-259, 2014, doi: 10.1016/j.tourman.2013.11.008.

[11] C. H. Liu, "Local and international perspectives of the influence of creative experiences of Chinese traditional culture on revisit intentions," Curr. Issues Tour., vol. 23, no. 1, pp. $\quad 17-35, \quad 2020, \quad$ doi: 10.1080/13683500.2018.1564740.

[12] M. J. Khan, S. Chelliah, and S. Ahmed, "Factors influencing destination image and visit intention among young women travellers: role of travel motivation, perceived risks, and travel constraints," Asia Pacific J. Tour. Res., vol. 22, no. 11, pp. 1139-1155, 2017, doi: 10.1080/10941665.2017.1374985.

[13] E. Y. T. Chew and S. A. Jahari, "Destination image as a mediator between perceived risks and revisit intention: A case of post-disaster Japan," Tour. Manag., vol. 40, pp. 382-393, 
2014, doi: 10.1016/j.tourman.2013.07.008.

[14] M. Yildırım and A. Güler, "Factor analysis of the COVID-19 Perceived Risk Scale: A preliminary study," Death Stud., vol. 0, no. 0, pp. $\quad 1-8, \quad 2020, \quad$ doi: 10.1080/07481187.2020.1784311.

[15] B. Nguyen Viet, H. P. Dang, and H. H. Nguyen, "Revisit intention and satisfaction: The role of destination image, perceived risk, and cultural contact," Cogent Bus. Manag., vol. 7, no. 1, 2020, doi: 10.1080/23311975.2020.1796249.

[16] T. Matiza, "Post-COVID-19 crisis travel behaviour: towards mitigating the effects of perceived risk," J. Tour. Futur., vol. 2012, no. April, 2020, doi: 10.1108/JTF-04-2020-0063.

[17] kompas.com, "Virtual Tour, Peluang Baru Pariwisata di Era New Normal," kompas.com, 2020.

https://travel.kompas.com/read/2020/05/09/21 0800427/virtual-tour-peluang-baru-pariwisatadi-era-new-normal?page=all $($ accessed Feb. 10, 2021).

[18] jawapos.com, "154 Destinasi Wisata di Jawa Timur mulai Reopening," jawapos.com, 2020. https://www.jawapos.com/surabaya/03/08/202 0/154-destinasi-wisata-di-jawa-timur-mulaireopening/ (accessed Feb. 10, 2021).

[19] Liputan6.com, "Kebun Binatang Surabaya Masih Jadi Primadona Tujuan Wisata Warga," liputan6.com, 2020. https://surabaya.liputan6.com/read/4399507/vi deo-kebun-binatang-surabaya-masih-jadiprimadona-tujuan-wisata-warga (accessed Feb. $15,2021)$.

[20] detikNews.com, "KBS Sepi di Hari Terakhir 2020, Besok di Prediksi Ramai," detikNews.com, 2020. https://news.detik.com/berita-jawa-timur/d5316667/kbs-sepi-di-hari-terakhir-2020besok-diprediksi-ramai (accessed Feb. 20, 2021).

[21] N. Thammadee, "The Effects of Travel Motivation, Satisfaction, and Attitude on Revisit Intention: A Case Study of East Asian Tourists in Thailand," Bus. Rev. J., vol. 7, no.
1, pp. 243-262, 2020.

[22] M. Kozak, Repeaters' behaviour at two distinct destinations, Annals of Tourism Research. 2001.

[23] L. L. Chang, K. F. Backman, and Y. C. Huang, "Creative tourism: a preliminary examination of creative tourists' motivation, experience, perceived value and revisit intention," Int. J. Cult. Tour. Hosp. Res., vol. 8, no. 4, pp. 401419, 2014, doi: 10.1108/IJCTHR-04-20140032.

[24] M. J. Khan, S. Chelliah, and S. Ahmed, "Intention to visit India among potential travellers: Role of travel motivation, perceived travel risks, and travel constraints," Tour. Hosp. Res., vol. 19, no. 3, pp. 351-367, 2019, doi: $10.1177 / 1467358417751025$

[25] D. Kartini, "The Influence of Cultural Values, Tourist Motivation, and Word Of Mouth towards the Destination Image and the Implications of Visit Intention (Study on Tourist Destinations in Yogyakarta)," Int. J. Manag. Sci. Bus. Res., no. 1, pp. 99-110, 2015.

[26] Lan-Lan Chang and Kenneth F. Backman, "An Investigation of Creative Tourists' ELan-Lan Chang, \& Kenneth F. Backman. (2016). An Investigation of Creative Tourists' Experience and Revisit Intention. Tourism Travel and Research Association: Advancing Tourism Research Globally, 23, 1-10. Retrieved," Tour. Travel Res. Assoc. Adv. Tour. Res. Glob., vol. 23, pp. 1-10, 2016, [Online]. Available: http://scholarworks.umass.edu/cgi/viewcontent .cgi?article $=1779 \&$ context=ttra\%0Ahttp://sch olarworks.umass.edu/ttra.

[27] B. C. Çetinsöz and Z. Ege, "Impacts of perceived risks on tourists' revisit intentions," Anatolia, vol. 24, no. 2, pp. 173-187, 2013, doi: 10.1080/13032917.2012.743921.

[28] J. Lily, "e-Review of Tourism Research (eRTR), Vol. 15, No. 6, 2018 http://ertr.tamu.edu," vol. 15 , no. 6 , pp. 540 $559,2018$. 